\title{
Pocketing Prayer, Pedagogy, and Purple Hair: A Story of Place and Belonging, 2010-2015
}

Flossie Peitsch

\begin{abstract}
The Prayer Pocket Place, is the ideal public pedagogical outcome of visual artistic practise. Its historical links, practical progressions, and successful teaching and learning processes are framed using narration, testimonials and the initiator's reflections. These outline Pockets' transformative articulation of its tricky subject matter - spirituality in the public sphere - and disclose how its widespread public endorsement and lasting place / belonging were gained.
\end{abstract}

\section{Keywords}

public art, spirituality, visual art, art practice, local history 

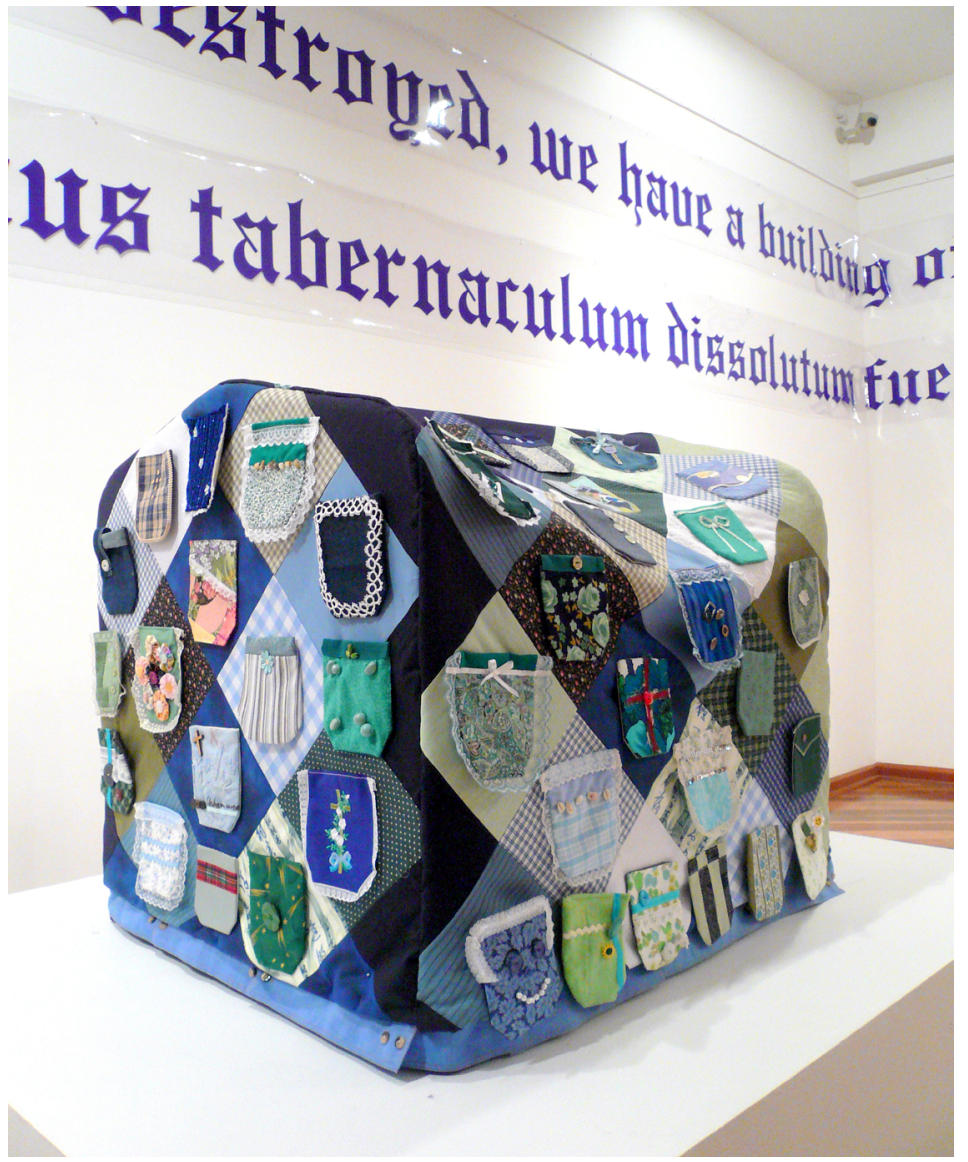

Figure 1: The Prayer Pocket Place, 2011
DESCRIPTION:

The Prayer Pocket Place, (Fig. 1)

is a multi-sensory installation

featuring over 300 hand-sewn

fabric, 'stand-alone', sealed pock-

ets containing prayers-women's

deepest wishes of wellbeing for

their families, communities and the universe. It presents as a sanctified space sheltering an interwoven soundscape. The pockets are made in monocolours-either whites, blues, or greens; or a combination of these.

DIMENSIONS:

A 3D work standing $1 \mathrm{~m} \times 1 \mathrm{~m} \times 1 \mathrm{~m}$ encompassing over 300 motifs, wrapped with a subtle soundscape. MEDIUM:

Mixed assemblage of aluminium, textile, wicker, with soundscape and audio equipment.

The Prayer Pocket Place (Fig 1) is not just 'something', but rather, it crafts a sensory-rich personal 'someplace' to contemplate the enduring facets of life's bigger picture. This public art project involved hundreds of women making Pockets. It literally and figuratively represents women in community and in the light of public pedagogy, its creation is a story worth the telling.

This article outlines the project's five-year development starting with its local historical influences as the preliminary artistic inspiration leading to its early in-gallery fabrication. Then it suggests why the project proceeded seamlessly from the author's earliest creative days, interrogating her own unique position in society as artist, mystic, mother, activist, and teacher.

With detailed affection capturing its overall sense of participation and empowerment, each layer of Pockets' development is stitched into the fabric of its story. Each workshop site and setting-constructing a wide national forum-adds a new covering incorporating the participants' joy and creativity.

As a final point, Pockets is described in terms of finding and making a lasting place and space for community - giving value and purpose to things not normally seen or commonly cherished among 'non-indigenous' people or society at large. These include wisdom, courage, relationship building, sense of well-being and spirituality.

Significantly, these outcomes emerge external to all educational institutions and academic research, yet, it is the very foundation needed to build a cultured and compassionate society. Pockets is the practice essential to public pedagogical research. Nonetheless, neither this article, nor the project, is more justified by being informed-as it were-by that body of research. 


\section{The Prayer Pocket Place, For Hearth, Hand, And Heart, 2010 - 2015 Pattern Outline}

After thirty-five years working as an artist within the framework public pedagogy-creating community through art-based projects, The Prayer Pocket Place grew spontaneously from my artistic response to local historical events in the Illawarra, NSW, while evolving into bona fide Fine Art. This Fine Art result is not to be confused with the artistic by-product of interactive 'socially transformative' art, newly termed 'The Educational Turn' (Luise, 2010). Pockets expanded extemporaneously through the passion the project itself generated in its devotees. One of my colleagues (Qadri, 2016) responds favourably: 'It is lovely how the project gathered momentum and I think that's because it provided a solution or an opportunity to write down prayers and hopes. It was useful for people and enjoyable and they saw a sense to it.' This comment documents a rewarding teaching and learning achievement.

The achieving participants, as part of the development of my solo exhibition entitled Sleeves \& Sheets, Socks \& Pockets, (concurrently exhibited at Wollongong City Gallery and Project Contemporary Art Space, Wollongong, NSW, 2011) took part in free Pockets workshops organized at various public venues over a five year period. Locations for workshops include the Wollongong Art Gallery, artist run spaces such as Project, cafes, private homes, Sydney Living Museums, newly immigrated women's hostels, Community Centres, church retreats, family groupings and many more. The partakers included migrant, stay-at-home and professional women of varying ages in temporary and discordant-due to differing interests, outlook, cultural background, spirituality, and socio/economic status-but purposeful groupings. The distinctive pockets (Fig 4) evidenced these women's creative variations.

Like every good folktale, the story of Pockets begins with the familiar tag, 'Once upon a time...' there was no Prayer Pocket Place. Then, an artist came to town.

\section{Artistic Inspiration}

The first instigating historical event is Australia's largest-ever industrial accident, the $\mathrm{Mt}$ Kembla Colliery Gas Explosion of 1902. This mining disaster (Fig 2) took the lives of ninety-six (96) men and boys, survived by mothers, wives, sisters and daughters. Yet, the town endured. I became interested in paying tribute to the brave women who carried on with their lives - having survived such dire personal tragedy. My goal was to gather 96 pockets.

The second instigating historical place is Meroogal (Fig 3) where the lives of four successive generations of Thorburn women living through hard times are acknowledged (Sydney Museums, 2016). These women are remembered as individuals contributing tirelessly to their well-being through their relationship to each other and to community-just as the surviving Mt Kembla widows.

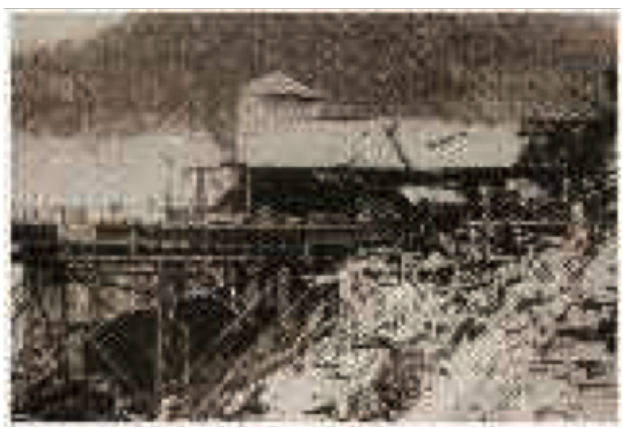

Figure 2: Mt Kembla Colliery

(Source: http://www.illawarracoal.com)

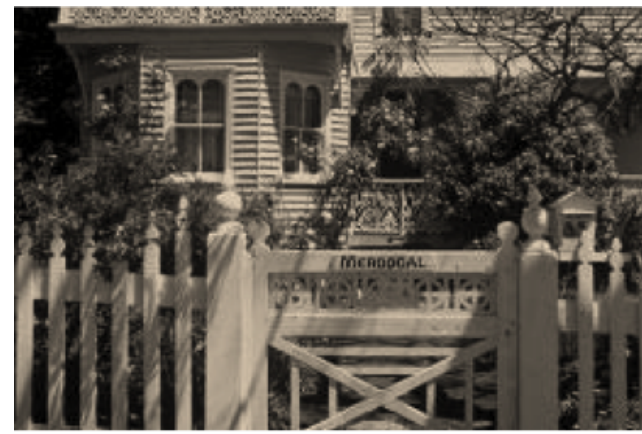

Figure 3: Meroogal

(Source: http://sydneylivingmuseums.com.au) 

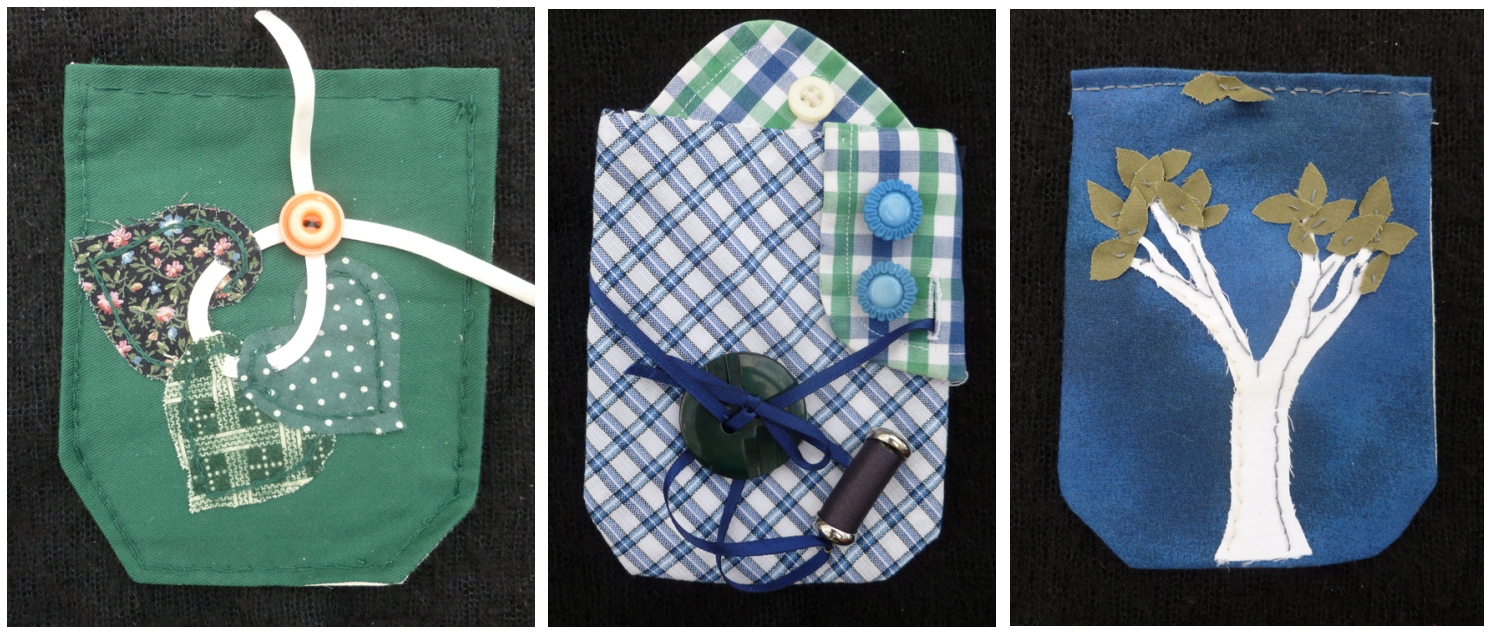

Figure 4: Examples of pockets from workshops (Photographed by Peitsch, 2011)

\section{Protagonist, Parenthood, Purple Hair and Pedagogy}

My Dad told my prospective husband on our engagement, 'You know, she is always going to be a force to contend with' (Stumpf, 1974) (Fig 5). He was not wrong I have seen. Since I properly began my artistic vocation as a zealous twenty year old, I have attempted to seamlessly sew together the ideologies of home, community, spirituality, and women's work (Peitsch 2008).

Conversely, I keenly felt first-hand the 'otherness' of the practising artist in her relationships to community. This 'non-placed-person' dichotomy became all the more poignant to me when I became a mother and, realized additionally the low regard in which this domestic station was held. I had no voice or position from which to invest in this conversation.

Eventually, I found my voice when my last baby was eighteen months and I, refusing to be the typical, speechless, coffee-clutching, doting parental unit, decided-as an artist-to articulate my notions pertaining to both spirituality and motherhood. I knew that the artist is an unexpected catalyst for change in society today. However, unlike now, the artist has long been sought out as a social prophet and altruistic protector of humanity: 'It appears likely that poets in our civilization, as it exists at present, must be difficult... the poet [or artist] must become more and more comprehensive, more allusive, more indirect, in order to force, to dislocate if necessary, language into their meaning [Inclusive language added]' (Eliot, 1921, p. 289). In fact, she has been expected to fearlessly raise the call to repentance in some inherent manner.

Never one to acquiesce, I necessarily became a postgrad student teasing out cultural conundrums. As an artist undertaking a Masters of Fine Art at Monash University, I embarked on formal research in my interest areas (Fig 6). As others before me, I found domestic themes would eventually lead me to resistance within the academic world. There, strict 'research' is still valued far above 'teaching and service' (Park 1996). My areas were still the ideologies of home, community, spirituality, and women's work-always cultivating a hands-on approach involving lay-people (Peitsch 2008).

With its close proximity to low income and migrant communities, at Victoria University, Footscray, Melbourne, I was encouraged to include collective projects in my creative PhD research. This allowed me to further explore, 'artistic ways of knowing and being in the world speaking within and to the public sphere' (PPI, 2016). I routinely create Fine Art projects existing outside of education programs, such as the project Chisholm's Homes (2006), where the fabricators are everyday people called upon to use their everyday acquired skills for fun and the greater good. 


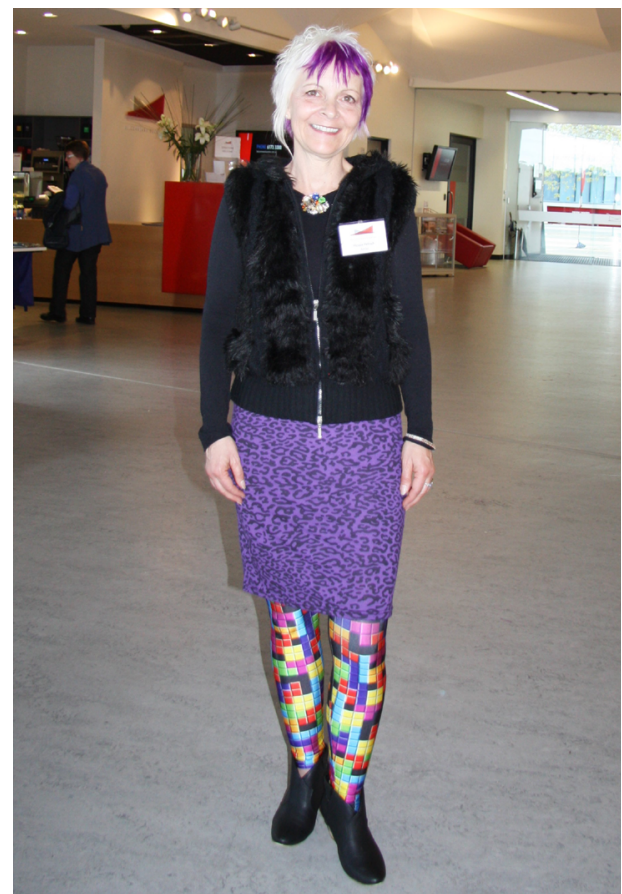

Figure 5: Flossie Peitsch, 2012

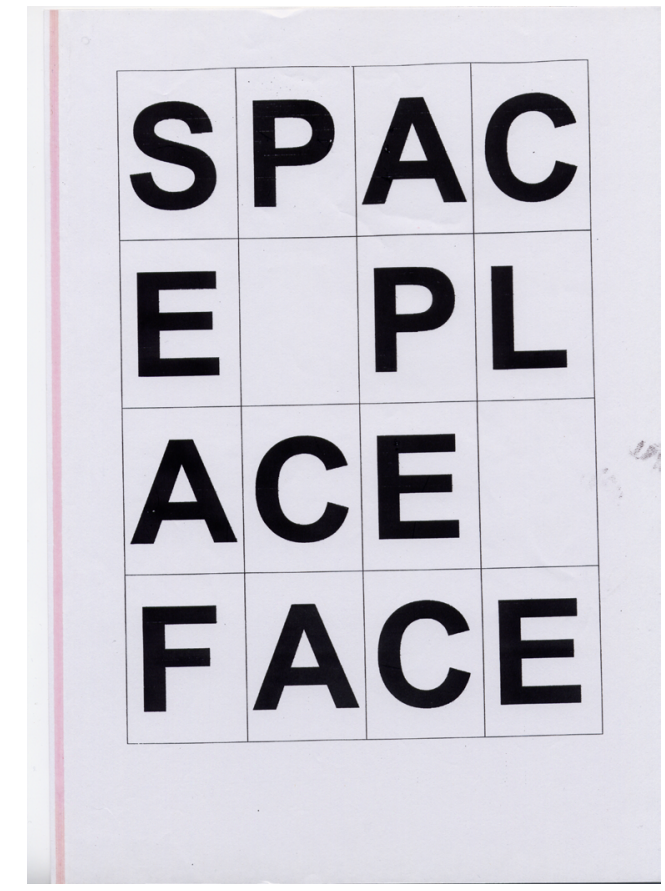

Figure 6: Theme Grid of the author's MFA (Peitsch, 2008)

One appreciative and articulate workshop participant wrote, 'I think the presentation was a very successful juxtaposition/intermarrying of theory and practise. You obviously knew what you were doing having done the academic groundwork so were able to show us the essential characteristics of narrative through performance. Well done.' (Wollongong, 2008). This general comment seems to apply to many of the workshops I conduct. And, I do feel 'on a mission from God' to quote the film The Blues Brothers (Landis 1980). 'The power that can transform, redeem, unify and order has moved in continuous process from a transcendent world into the inner being of artists themselves' (Norris, 1996, p. 59) so John Cobbs has written. Even my purple hair which is worrying and in fact, alienating to some private school systems I discovered, is welcomed in the creative circles in which I nominate to move (2012). Like my unnatural purple hair, alternative teaching and learning practises and places are a natural way ahead for me (2008). Pockets is one such chapter in this line of thinking.

\section{Opening Pockets}

\section{Lutheran Women's Retreats In Victoria, 2002}

As the forerunner to The Prayer Pocket Place, the first one hundred plus (100+) pockets I facilitated were personal 'devotional aids' (Fig 7), repositories for a woman's own prayer life. I was invited to be the state-wide Leader in retreats which usually have a Bible-study-based, lecture-style delivery. Instead, I wished to assist the women in taking their beliefs 'out for a spin', sharing their everyday spiritual journeys and family situations in a non-threatening way. So, I implemented sewing circles.

Sorted into small groups, I encouraged participants at each of five Lutheran Women's Retreats to sew buttons on the pockets they had newly constructed to represent family members, while participating in 'directed conversations' about families and faith. They then privately wrote prayers about each person. The pockets were taken home and kept in safe places. 


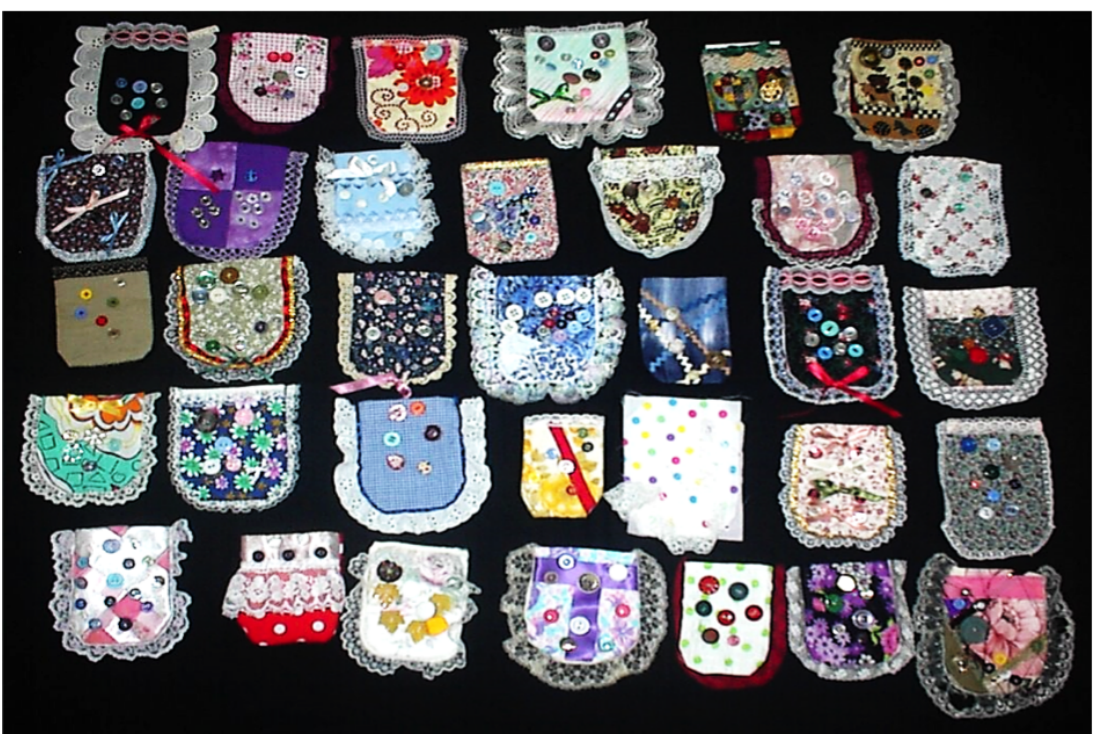

Figure 7: Pockets (photographed by the author)

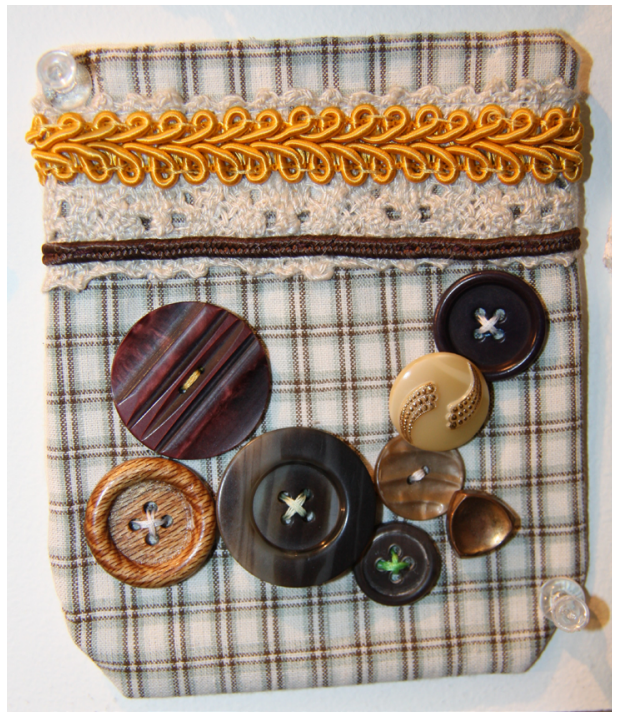

Figure 9: Sample pocket with buttons (Peitsch, 2011)

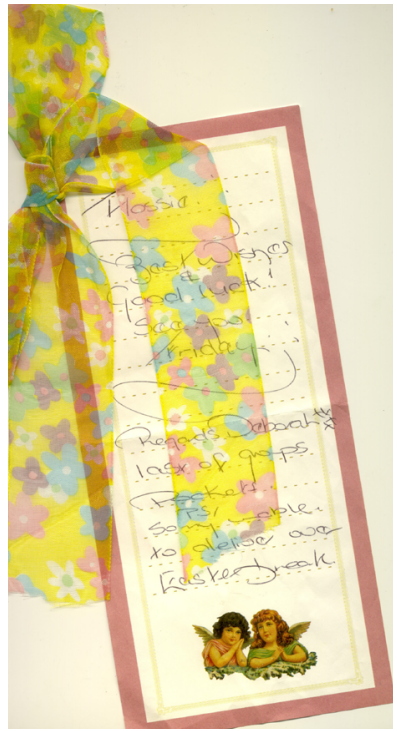

Figure 8: Note from workshop participant (Peitsch, 2011)

One woman named Grace placed her pocket safely on her fridge. She continued to add buttons as her family grew. Years later at age 86, this woman passed away. Her pocket (Fig 9), one of the last items taken from her house, was given to her eldest daughter who was surprised to find what was inside-a prayer for each of the children wanting them to have the same happiness, simplicity and blessings in their lives that she'd had (Schmaal 2012).

This heart-warming story shows my unconventional approach for the retreats to have been well received by the women, especially considering the years of rock-solid tradition I had challenged.

People's shared personal stories are brave, enlightening, powerful, and self-productive. 'Personal experience is the source of reliable knowledge' (Stackhouse 1997, pp. 51-52). The journey sharing this knowledge is also noteworthy. 'The narrative text refuses the impulse to abstract and explain, stressing the journey over the destination, and thus eclipses the scientific 
illusion of control and mastery... evocative stories activate subjectivity and compel emotional response' (Bouchner 2000, p. 745). Pedagogy in this way encourages the development of lasting closeness and a collective sense of belonging.

There are many ways in which the self-narrative journey can be valuable. 'All these creative forms exact a distancing, helping one to experience the self as other, as encouraged in postmodern ethnography' (Bouchner, 2000, pp. 520-521) but usually this kind of self-disclosure is not given a safe 'place' in our society. Writing or talking from this vantage point presupposes a difficult journey into the unknown. Cixous (1937, p. 204) describes this as travelling through 'our own marshes, our own mud...it is deep in my body, further down, behind thought.' In artistic terms, it is 'transcending the visible in one's own way, making visible the invisible' (Jung, 1981, p. 37) [inclusive language added]. This points healthily to greater self-awareness and the wider inclusive community benefit towards well-being. It is social pedagogy at its most productive.

\section{Sleeves \& Sheets, Socks \& Pockets}

The Prayer Pocket Place encouraged further conversations beyond the processes of artistic inquiry as the heartfelt centre of this new solo art exhibition. Referred to here as SSSP (Sleeves \& Sheets, Socks \& Pockets, 2011), this solo exhibition of installation sculpture became a productive tool for teaching and learning-gaining recognition for women's role in community well-being. I gained a heart for the women of the Illawarra and their mostly immigrant past.

The research base for its fine art derived partially from the work of noted humanitarian Caroline Chisholm, an immigrant in local Shell Harbour, and my own Doctoral research. Looking at the history of women at work in the Illawarra since the 1850s and adding in my own brief experience here in this place, I see a highly textured patchwork of dislocation,
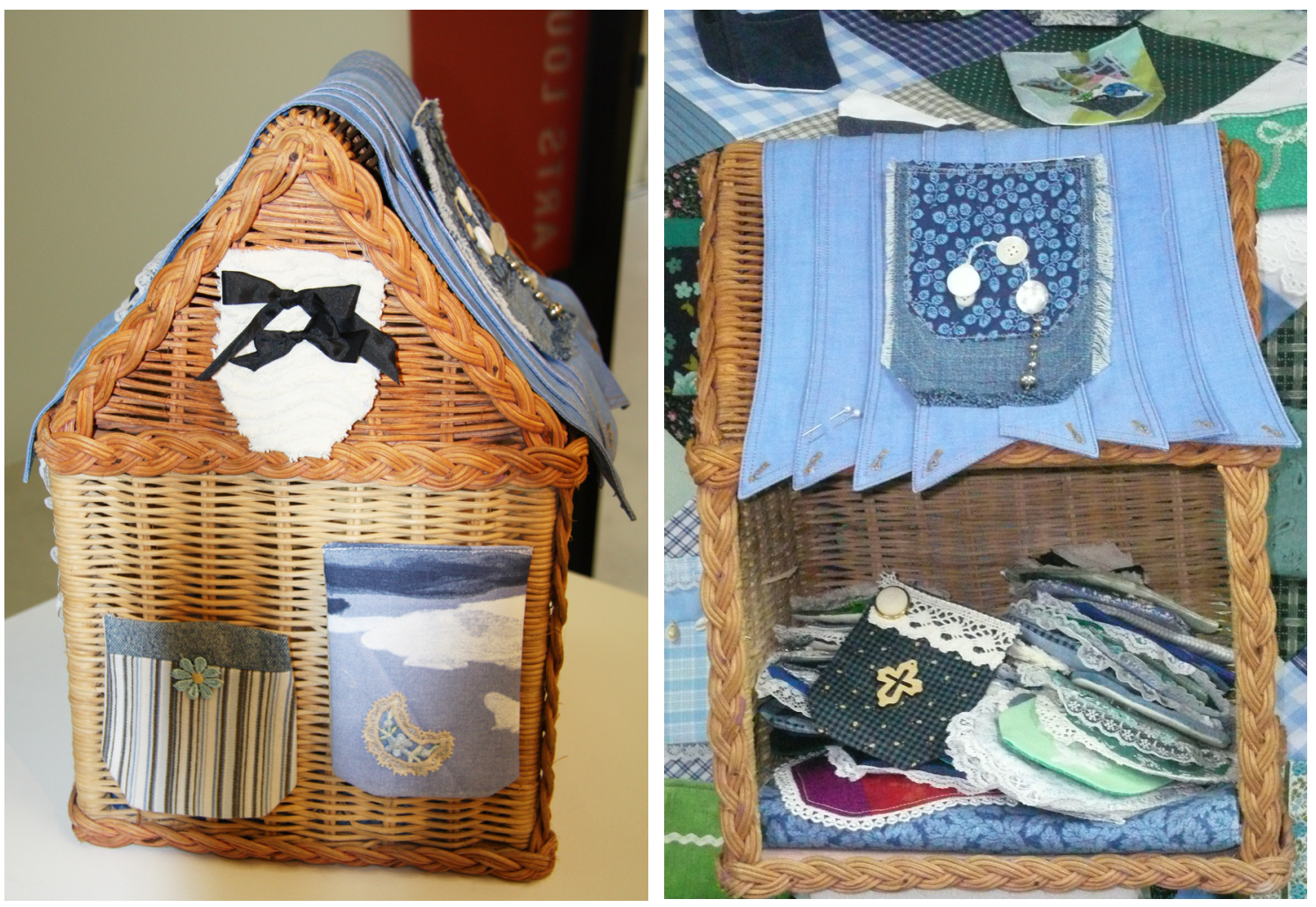

Figure $11 \& 12$ : Small hut of pockets (Peitsch, 2011) 
loss, and alienation covered with adaptability, diligence, and resilience-cultural transition within Diaspora. My art is an interpretive sampler of women as 'the fabric of society' (Peitsch et al. 2011).

Women-seemingly intuitively-often deal with caring and struggle, spirituality and belonging for those they bring into the world and others. All these things are hidden in women's hearts and in this project, in the pockets. In her published essay for SSSP, Hulsbusch (2011) writes:

It is the pockets that harbor personal secrets. Pockets keep ideological, political, spiritual and personal thoughts, items of the past and aspirations for the future. These items of clothing and household linens operate as conduits to inform us of women's position in society... encapsulated by the ordinariness of a lived reality. Caroline Chisholm would approve.

Capturing the essence of public pedagogy through art, SSSP was seen to accomplish this: 'Her textured studio enquiry unravelled cultural mores and belief systems, unpicked gender-based ethics, disentangled ethnic identities and started to mend the fray, darn the holes and re-weave the patches...' (2011). Pockets are evocative of the ideas of home/community by creating a specific place holding each woman's hand-written letter of the thoughts, hopes and prayers of all time, place and culture.

\section{Wollongong Women's Workshops}

To initiate community interest and engagement in SSSP, I advertised pocket-making workshops at the Wollongong City Gallery (March, 2011). The flyer simply said:

A Prayer Pocket is a small, flat cloth 'pocket' made to hold a woman's written eternal wishes for the wellbeing of her family and community. Created from a simple set pattern, sewn or glued, decorated and sealed shut. These works will form part of an exhibition at WCG in 2011.

This is where the Pockets story took its current shape, in three dimensions. I had expected to need to gently lead people into the awareness of spirituality and their possible connection with the divine. Then, I had planned to teach them how to sew a pocket (Fig. 10). This was not to be the case. The women who came to the workshops were completely comfortable in writing their own texts, in their own ways without any theological input or my insight into the eternal world.

The prayers poured from their hearts, in their own languages, in their own ways, with ease. I had clearly tapped into a deep stream. I had merely supplied the idea, the opportunity, the fabric, notepaper and sewing machines. Apart from a little sewing guidance, the women did everything without my direction. I found it miraculous to experience this accessible-and possibly universal-sense of innate spirituality and connectedness. I was being 'taught' in my own workshop for others.

As the facilitator, I feel a most important aspect of this project is the fact that the pockets were immediately sewn shut by their makers after the prayers were inserted. This meant that the prayers remain forever personal, private, and protected from human interference and possible interpretation or distortion.

One of the notes (Fig 8) I received was from the coordinator of an immigrant women's hostel where she runs workshops in the Illawarra. Every few days I discovered another set of new pockets in my post box, delivered there with flying ribbons and notes attached. The note reads: 'Flossie, Best wishes \& Good luck! See you Friday. Regards Deborah xxxx Last of the groups' pockets. PS. Sorry unable to deliver over the Easter break.' 


\section{Work'n Women Forum}

Using the vehicle of public pedagogy and an additional placing of the pockets, I became the originator and director of a free two day public forum related to the SSSP exhibition. I called for the submission of presentations for and by local women. The topics were grouped into the areas: Women \& History; Women \& Work; and Women \& Wellbeing. The all day sessions were based at both the WCG and Project Gallery and included excursions to historical Mt Kembla and the Illawarra Museum. The program included a one act play by local playwright and actor, Wendy Richardson (Latifi 2015); Social Sculpture Events by myself; talks by local museums' directors, from new migrant groups, artists, and historians, a women's fitness workout, a labyrinth experience and spiritual music performance, Circus Wow; an audiologist; a sexuality psychologist; outback perspectives; dramatized personal histories by local university students; Sharon Bird, the local MP giving her politicians' view on Women at Work and more.

As an unobtrusive witness, Pockets offered its sanctuary of place throughout the proceedings. Seeing the value of this forum for local history and community benefit, it was sponsored by Mt Kembla Mining Heritage and the Migrant Heritage Project, following my approach to them.

\section{Meroogal Women's Arts Prize, 2011}

The next approached stage for Pockets was its entry to Made by Hand, an exhibition sponsored by NSW's Historic Houses Trust seeking art that highlighted women's contributions to the culture of place, particularly as found at Meroogal. Meroogal, itself, is a pocket of four generations of Thorburn women's history, as mentioned earlier in this essay. Its significance is outlined with these words 'The house still overflows with their belongings - favourite books and ornaments, furniture, photographs, diaries and journals, newspaper clippings, receipts and recipes, appliances and clothes - and the garden, ... still provides fruits and fresh produce that hint at their self-sufficiency and hospitality' (Sydney Living Museums, 2016).

For good effect and fun in this part of the project, I collaborated with local musician Wendy Suiter who, pocketing the voices of the numerous community textile fabricators during the workshops, crafted an original soundscape using audio excerpts from Pockets workshops (Suiter 2016). One basis for the workshop recordings included using the original parlour chats initiated and recorded by one of the Thorburn sisters who did not like handwork, doing so while the others did their embroideries. Emanating from The Prayer Pocket Place with an underlying quilt of sound, are the 70 individually made sound motifs of voices/ sounds of the shared ritual of making the 70 external pockets. This soundscape fashioned an additional and unique inner layer to the sculpture. Pockets now became a remarkable audio/ visual installation.

\section{Women's Prayer Pocket Place Visits Canberra Lutheran Women, NSW, Two Day Workshop, March 2012}

I was once again invited to direct and present a workshop for Lutheran Women in NSWsimilar to those in the Victoria but this time using the Illawarra theme of Pockets as the uniting craft.

Without detailing the unique activities of the weekend, the following are some excerpts from notes and letters I received following the Pockets workshops. 
Sample 1: Excerpt from a letter, penned on April 12th, 2012:

Dear Flossie, The Retreat is fading into the distance but thankfully, was not one of those which fades completely ...far from it. It's ripple will have moved far-for me personally-well -it removed (perhaps) the last brick from the wall of depression... I'm eternally grateful. Thank you. Love Alicia' (Alicia, 2012)

Sample 2: Excerpt from a posted letter and package received some weeks following the Retreat:

'Dear Flossie, I would like you to have Myrtle the Mermaid (Fig 13) whom I made from a sock after your Pockets event. She isn't young or beautiful, in the classic sense, but she is strong and vibrant, self-assured and probably a bit bossy. I hope she finds her place to shine. I really enjoyed the weekend at Warrambui. I have come home bursting with ideas and eager to get into creative projects. In the last week I have... [long list of art and craft projects]. Thank you so much for your inspiration and input into the weekend. You've been a real blessing at a time when it was sorely needed... May your creative juices flow eternally on. God bless you, Judy M

Sample 3:

'I thought I wasn't a very creative person, but when I looked at my prayer pocket in the end, I could see that it was not only beautiful but it also told a story about God's presence in our lives', said one retreat participant. 'I'm going to stop saying "I'm not creative", because I am.' (Schmaal, 2012)

Pictured below (Fig 14) is the installation setting of the pockets created during the Women's Retreat weekend. In this formation, the pockets were the central focus of a unique-to-this-denomination, 'all women led' worship service.

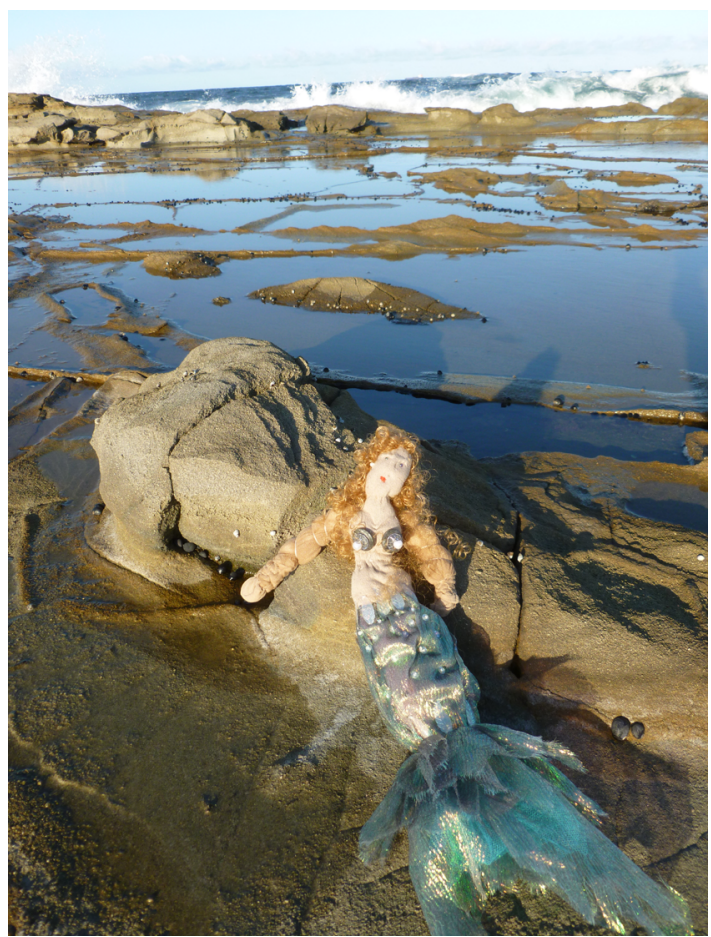

Figure 13: Myrtle the Mermaid (photographed by Peitsch, 2012)

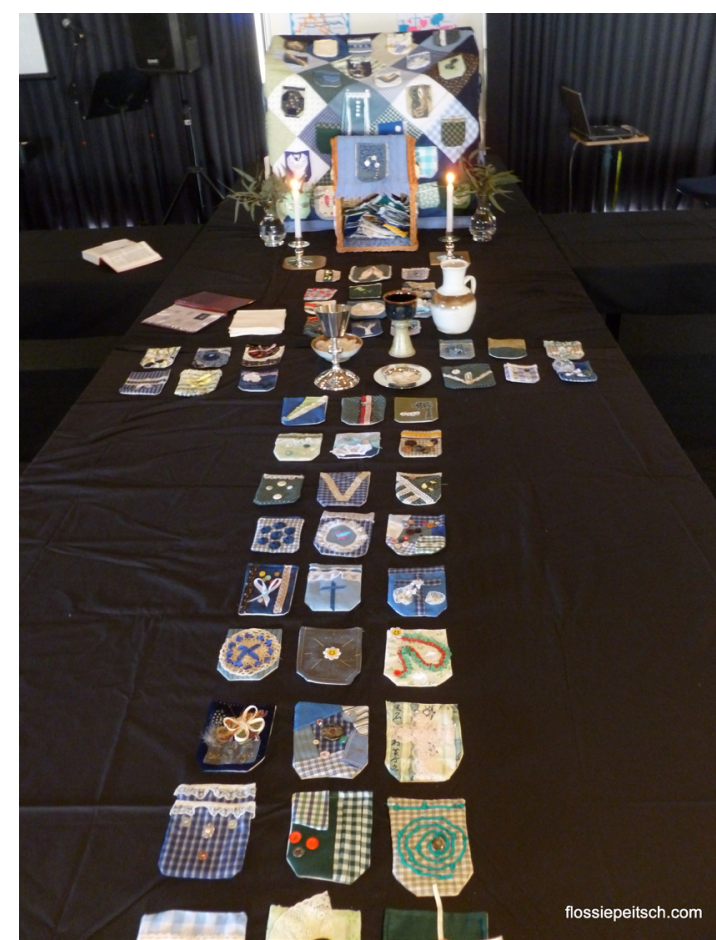

Figure 14: Cross in worship centre (Peitsch, 2012) 


\section{Canberra Belconnen Arts Centre, September-October 2012}

Pockets gained a gallery space of its own at the Centre and compellingly filled its place with subtle sound and sanctity. It was venerated by those who visited it there - some being the makers of the pockets at the Canberra Retreat. People remarked on the quieting effect of entering its space at the gallery. Pockets seemed to emanate a sense of worshipfulness-drawing together women from all periods and places: 'Worship breaks the boundaries of space and time' (2016). Here are some excerpts from comments in the Guest Book from the Pockets exhibition:

Wow! What a lot of great pockets! I won't forget the pockets!-Delightful, inspirational! Thank you, a beautiful exhibition in this sympathetic space.-Amazing! Fascinating! Each so different. Just lovely!-I like all the pockets but I like my grandma's best. Thank you for putting it here for us to see. (Georgie age 8)-Great to see all our handwork on display. Thanks.-This exhibition creates a lovely warm sense of 'togetherness'.-A wonderful concept women's work, hands and heart, remembering loved ones lost.-Looks like Earth! Blue-Sky \& Sea, White-Cloud, Green-Land; Sound is People. Many pockets-Countries. So interesting!!! I like this-a small pocket Earth.

The last comment in the group adds that viewer's imaginative extension to what lay in front of her. It realizes these knowing words, 'The creative and imaginative efforts of all of us count, and nothing less than the health of the world hangs in the balance' (Gatehouse, 2016). Pockets had now assumed its own presence and raison d'etre. Helping people feel good about themselves by having their handiwork praised is good for the general well-being of society.

\section{Mt Kembla Mining Heritage Inc Collection}

Always the hoped outcome for Pockets, this sculpture was acquired for permanent exhibition by the Mt Kembla Mining Heritage in January, 2014, with due ceremony and officiating. It resides among collected memorabilia, staging an effective vigil to the history of Mt Kembla. It can be visited by its public at any time-and it is hoped, for all time.

\section{Pocketing Place And Belonging Accessibility Of Place And Belonging}

Due to raised awareness towards some religions and religious people, the 'every day' person may consider spirituality a taboo subject. This was not the approach demonstrated within the Pockets project. Participants found a place of belonging usually reserved for close communities. Through the workshop community, they felt safe and supported in making a private and most personal approach to the divine. In Pockets, people eagerly embraced the opportunity to commit their inner selves to paper and permanency. Given that, 'Once past the age of thirty, it is even somewhat surprising to make a new friend. It can be extraordinary and odd to start an impromptu conversation with an unknown person in a public place,' (Botton, 2012, p. 23) this occurrence bears further reflection.

To consider the surprising effectiveness of Pockets as a public pedagogy artefact, one must interrogate this century's wider situation of spirituality within the Australian setting. Lorraine Gatehouse (2016, p. 4) suggests that the cultural crisis of this decade is producing a resultant spiritual crisis, '... a time for reassessing just who we are, who we want to be and where we are going'. 


\section{Pockets' Provision of Place}

Sadly, attitudes toward belief systems are not often realized apart from the community's usual stereotyping and demarcation of religions. So in alliance with current sensibilities, few places encourage the average person to reflect upon their own spirituality-being one of four basic human needs (Wilber, 2000)-education notwithstanding (2014). As such, the only place I found evidence of a spiritual discussion was in the stalls of the women's toilets at the University of Wollongong (2012).

We have constructed an intellectual world whose most celebrated institution [the university] rarely consents to ask, let alone answer, the most serious questions of the soul...the current subjects do not in themselves track the themes that most torment and affect our souls. (Botton, 2012, p. 121)

Pockets unilaterally encouraged the sharing of common struggles by a simple ritual joining in written supplication. Valuable activities such as these 'are what help to hold our fractious and fragile societies together' (Botton, 2012, p. 50)

A person's belief system and visual coding is affected by their period in history, their cultural influence, and social class as highly shaped by the dominant society, plus their personal spiritual journey. No one is exempt from these influencing factors. But, the artist may be a conduit or productive influence for spiritual awareness and understanding. Norris writes, 'Our task is not to convince, but to suggest, evoke, explore' (Norris, 1996, p. 55). Pockets gently facilitated an opportunity for participants to step outside their usual settings-that of the dominant society they typically embody-and enjoy a wider communion belonging with other women-from the past, present and future-knowing that through love, all women experience life's loss and gain. Through the tender art of Pockets, I explore the role of faith in building a harmonious multi-cultural society (2002)

\section{Wider Provision of Place}

At many art and spirituality workshops, I pose a few introductory questions. In chart form (Appendix 1) are the responses given at several workshops this year-held apart from educational institutions.

Once a person acknowledges her universal questioning of the divine, she considers what it means to be human, and a door opens to a collective consciousness where steps can be made towards the possibility of something quite new and positive within society (Fox, 2011). It is only a step-but an important step in understanding the implications of what it is to be called to life-not a new religion (Elwell, 2001).

\section{Prayer Bookend}

Achieved totally outside educational institutions, the hands-on task and self-directed sharing in small working groups led to personal healing, community building with a strong sense of belonging and solidarity, personal empowerment, realization of hope and activation for the future. Pockets became, quite innocently in itself, a powerful 'form of sociality and creativity' (Peters, 2015). It is newly part of the permanent display in the local museum, the Mt Kembla Mining Heritage Centre.

I have been quoted by Schmaal (2012) as saying:

'Everyone is an artist. Many more things in our lives are more creative than we realise. This also applies to the prayer pockets: it's not just about what you have produced, but it's 
about the journey we take to make them and how we change as people. You came up with something from just old scraps of material. Like life, you are involved in the whole process, making decisions, adding decoration according to your own personality or needs, using opportunities or difficulties and other potentials, from your earliest days to the end ... all under the grace of God'.

I feel strongly that the above as stated is the essence and purpose of Pockets. Aligning Pockets with public pedagogical research, problematic as even the terms of this field continue to be (Burdick, et al., 2014), is not the purpose nor intent of my article. It is not my area of research, expertise nor passion. I am an academic, but I authored this article as a practitioner. This is a consideration for the research journals-not only pertinent to me (Burdick \& Sandlin, 2010). The 'initiating', the 'doing' and 'the deconstruction' of The Prayer Pocket Place project, from start to finish, gives it its rightful place. My purpose in writing this article is to bring to light and interrogate a profound public pedagogical project. It is a story of small pieces bring profound.

The last small pocket (Fig 15) to be added in The Prayer Pocket Place story is the one filled by participants at the conference, Turning Learning Insideout (Charman, 2015) during my session. It fittingly holds the prayers of those who, in many ways, engage alternately with the story of their 'island home' Australia, as does Tim Winton (2015) who, like the authors of these tiny supplications, sees the earth as home and so, sacred. For those who can, this means the sacredness of place and belonging is here for the taking.

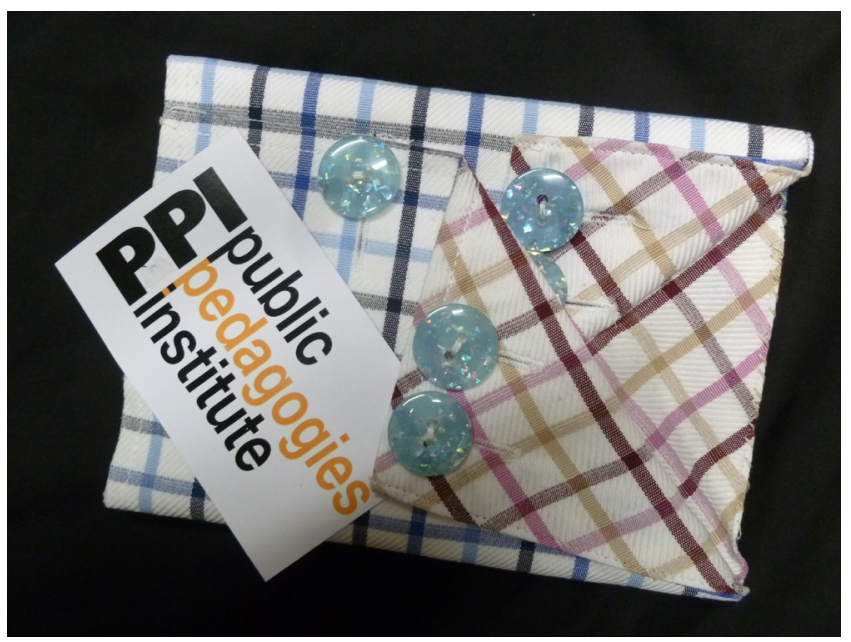

Figure 15: Pocket from the PPI conference (Peitsch, 2015)

\section{References}

Alicia, S 2012, Personal Correspondence

Australian Composers, Wirripang: Home of Australian Composers, viewed 20 Apr 2016, $<$ http://australiancomposers.com.au/composers/wendysuiter.html>

Australian Music Centre 2016, Wendy Suiter: Associate Artist, viewed 3 May 2016, <http:// www.australianmusiccentre.com.au/artist/suiter-wendy>

Belconnen Arts Centre 2016, Belconnen Arts Centre, viewed 18 April 2016 <http://www. belconnenartscentre.com.au>

Botton, A 2012, Religion for Atheists: A Non beleiver's Guide to the Uses of Reigion, Penguin, 
London

Bouchner, E 2000, 'Autoethnography, Personal Narrative, Reflexivity: Research as Subject', Denzin, Norman, Lincoln \& Yvonna, eds. Handbook of Qualitiveresearch, Sage Publications, California

Burdick, J, Sandlin, J. A. \& O’Malley, M. P., 2014. Problematizing Public Pedagogy, Routledge, New York

Charman, K 2015. Turning Learning Insideout: Learning and Teaching Beyond the Classroom, Footscray, Melbourne

Circus Wow 2016, Circus Wow, viewed 3 May 2016, <http://www.circuswow.org.au>

Cixous, H 1937, The Helene Cixous Reader, Routledge, London

Eliot, T. S. 1921, 'The Metaphysical Peots', Selected Essays, Faber \& Faber, London

Elwell, W. (Ed) 2001. 'Bonhoeffer, Dietrich', Evangelical Dictionary of Theology, Baker Reference Library, Baker Academic, pp. 181 - 184.

Fox M, 2011, Christian Mystics, New World library, Novato

Gatehouse L, 2016, Reflections, Pools of Silence Issue No 48, Feb, pp. 8-9.

Hulsbosch M, Monteleone J \& Peitsch F 2011, Sleeves \& Sheets, Socks \& Pockets: A Textured Studio Inquiry into Women's Work in the Illawarra, Wollongong Art Gallery, Wollongong

Illawara Coal, Mt Kembla Colliery Explosion 1902, viewed 18 April 2016, <http://www. illawarracoal.com/mtkembla.jpg>

Illawara Migration Heritage Project 2006, Migrant Heritage Project Wollongong, viewed 30 april 2016 <http://www.mhpillawarra.com>

Jung, H 1981, Art and the Question of Meaning, Crossroad, New York

Kidall, S 2015, Sally Kidall Blog, viewed 4 May 2016 <https://sallykidall.wordpress.com> .

Landis, J 1980, The Blues Brothers, USA: Universal Pictures.

Latifi, A 2015. Mount Kembla playwright Wendy Richardson passionate about helping others, viewed 3 May 2016 <http://www.illawarramercury.com.au/story/2917147/playwrightskeen-to-close-the-gap $>$

Luise, M., 2010. The Indypendent Essay: A Look at Art and Public Pedagogy in New York City, viewed 23 August, 2016, <https://indypendent.org/2010/06/02/essay-look-artand-public-pedagogy-new-york-city>

Mt Kembla Heritage Inc. 2015, Mt Kembla, viewed 28 april 2016, <http://www. mtkembla.org.au>

Mt Kembla Mining Heritage Inc. 2015, Mt Kembla Mining Heritage, viewed 30 April 2016 <http://www.mtkembla.org.au/\#!tours/kuveu>

Norris, K 1996, The Cloister Walk, Riverhead Books, New York

Park, S M, Jan-Feb, 1996, 'Research, Teaching, and Service: Why Shouldn't Women's Work Count?', The Journal of Higher Education, 67(1), pp. 46 - 84.

Peitsch, F., 2002. Word and Image ppt. Brisbane

Peitsch, F 2005, Caroline Chisholm at Living Museum of the West, viewed 18 April 2016, 
<http://www.livingmuseum.org.au/chisholms\%20homes/projectoutline/index.html>

Peitsch, F 2005, Chisholm's Homes, viewed 18 April 2016, <http://exhibitions.flossiepeitsch. com/chisholms_homes/chisholms/index.html>

Peitsch, F 2006, Art and Soul, 1st ed. Macmillan Art Publishing, Melbourne

Peitsch, F 2008. The Immortal Now:Visualizing the place Where Spirituality and Today's Families Meet. First ed. VDM Verlag, Saarbrucken

Peitsch, F 2012, Belconnen Dolly, Belconnen Arts Centre

Peitsch, F., 2012. 'The Immortal Now: Life after Research', in M. Ryan, ed. Reflections on Learning, Life and Work, Sense Publishers, Rotterdam, pp. 255-272.

Peitsch, F, MacKenna, T. \& Smith, S 2014, 'A Difficult Dinner Party - Being loved and Safe: how Spirituality in Education Can Open Inclusive Practices', Creative Approaches to Research, 7(2).

Peitsch, M 2000, The Prayer Pocket Places, viewed 20 April 2016, <http://flossiepeitsch. com/index.php?option=com_content \&view=article\&id=20\&Itemid=33>

Peitsch, T 2016, Church Bulletin, May 1st 2016, OELCA, Croydon Hills

Peters, C 2015, 'Re-imagining spaces, collectivity, and the political dimension of contempoerary art', Policy Futures in Education, Vol 13(1), pp. 149 - 159.

PPI, 2016, Journal of Public Pedagies: Author Guidlines, viewed18 April 2016, <http:// public pedagogies.org/journal/index.php/content>

Project Gallery, Project Gallery, viewed 20 April 2016, <www.projectgallery.com.au>

Qadri, D., 2016, Email Correspondence, Melbourne

Schmaal, S 2012, 'A pocket full of Grace' The Lutheran, May, p. 11.

Schmaal, S., 2012, Everyone's an artist: LWNSW retreat, viewed 30 Apr 2016, <http://www. lca.org.au/everyones-an-artist-lwnsw-retreat.html>

South Australian Government 2013, Statement Of Heritage Significance Onkaparinga Mill, Adelaide, <http://www.environment.sa.gov.au/.../heritage-register-lobethal-woollen-mill>

Stackhouse, M 1997, Covenant and Commitments: Faith, Family, and Economic Life, Westminster John Knox Press, Louisville

Stumpf, E 1974, Undocumented conversation, Kitchener

Sydney Living Museums 2016, Meroogal, viewed 28 april 2016, <http:// sydneylivingmuseums.com.au/meroogal>

Wilber, W. \& 2000, 'Psychology: Consciousness, Spirit, Psychology', Therapy, 1st ed. Shambhala, Boston

Winton, T 2015, Island Home: A landscape Memoir, Pan Macmillan, London

Wollongong City Gallery, Wollongong City Gallery, viewed 20 April 2016, <www. wollongongartgallery.com>

Wollongong University 2008, Narrative Inquiry: Breathing Life into Talk, Text and the Visual, <http://www.conferencealerts.com/show-event?id=ca13iami> 


\section{Appendix 1}

\begin{tabular}{|l|l|}
\hline \multicolumn{2}{|c|}{ SPIRITUALITY SURVEY - CHART 3 } \\
\hline \multicolumn{2}{|c|}{$\begin{array}{c}\text { Completed by general public attending my Art \& Soul Workshop, Royal South } \\
\text { Austran Society of the Arts (RSASA), Adelaide, March 2016 }\end{array}$} \\
\hline $\begin{array}{l}\text { WHAT Do I KNOW AB OUT 'THE } \\
\text { DIVINE' }\end{array}$ & $\begin{array}{l}\text { WHAT DO I WANT TO KNOW ABOUT } \\
\text { 'THE DIVINE' }\end{array}$ \\
\hline $\begin{array}{l}\text { He is my guide and counsellor, he is } \\
\text { ever present, guiding everything I do }\end{array}$ & Who he is? What he is? \\
\hline Awesome & ? \\
\hline I am loved and have a purpose & Peace in regard to God's plan for me \\
\hline Jesus & More \\
\hline Of the Spirit & More \\
\hline $\begin{array}{l}\text { The Divine is in and interested in } \\
\text { human endeavour }\end{array}$ & I would see the Divine in human activity. \\
\hline The spiritual exists & Do we have life after death? \\
\hline $\begin{array}{l}\text { My comprehension of the divine and } \\
\text { spirituality revolved around nature and } \\
\text { the forces of spiritual forces }\end{array}$ & A learning process of the understanding \\
\hline of nature and the spiritual world. \\
\hline Holy & Create \\
\hline God is & When I lose you where are you? \\
\hline Eternal & The essence of the eternal in myself. \\
\hline Jesus & More \\
\hline Forgiving & Know enough! Through church. \\
\hline Infinitecomplexity & Evolutionary relationship \\
\hline Very powerful & Why it is so important to us. \\
\hline Faith & Clarify \\
\hline $\begin{array}{l}\text { Unknowable (I have a BTh I know I } \\
\text { don't know) }\end{array}$ & Acceptance (that I don't know) \\
\hline Nothing & Everything \\
\hline Spirituality is our divine connectivity & God is in the everyday \\
\hline Unfathomable & \\
\hline Perfect & Will \\
\hline
\end{tabular}

\begin{tabular}{|l|l|}
\hline \multicolumn{2}{|c|}{ SPIRITUALITY SURVEY = CHART 4 } \\
\hline \multicolumn{1}{|c|}{$\begin{array}{c}\text { Completed by Christian Artists at my Art \& Soul Workshop, Chapel on Station } \\
\text { Gallery, Box Hill, Melbourne, April 2016 }\end{array}$} \\
\hline $\begin{array}{l}\text { WHAT DO I KNOW ABOUT } \\
\text { 'SPITUALITY' }\end{array}$ & \multicolumn{1}{c|}{$\begin{array}{c}\text { WHAT DO I WANT TO KNOW } \\
\text { ABOUT 'sP IRITUALITY' }\end{array}$} \\
\hline Created me and loves it dearly & How best to respond. \\
\hline The concept of the divine is elusive & $\begin{array}{l}\text { How could this concept be interpreted } \\
\text { through my art }\end{array}$ \\
\hline I'm known completely & More deeply \\
\hline Mystery & How am I connected? \\
\hline Love & How to be more loving \\
\hline Loving...eternal...compassion & Where is he? So much \\
\hline He is real/evident & How he thinks/his will for me \\
\hline $\begin{array}{l}\text { It's a force-wave that flows through } \\
\text { everything }\end{array}$ & That says it all \\
\hline What I know & More. The unfolding \\
\hline God is kind. & The next thing. \\
\hline Love & Love \\
\hline Immense guidance & Extent \\
\hline Everywhere & Why is suffering allowed? \\
\hline We are on first name terms & More experiences \\
\hline Creator & Certainty \\
\hline Present in presence & How to be always present to presence \\
\hline Love infused Cosmos & God?...but not pantheism! \\
\hline
\end{tabular}

\section{About the Author}

Visual artist and creative art educator, I seek the immortal now - seeing myself as a 'visual art' theologian with interests in contemporary spirituality and community. 'Splace' is my PhD invented term, engaging the voice of art for the self-realization of being, researching life's ultimate questions-Who am I? Where am I? Why am I here?

flossie.peitsch@gmail.com 